\title{
Propensity score matching analysis of the prognosis for the rare oxyphilic subtype of thyroid cancer (Hurthle cell carcinoma)
}

\author{
Yiquan Xiong ${ }^{1, *}$, Qiuyang Zhao ${ }^{1, *}$, Zhi Li $^{1}$, Shuntao Wang ${ }^{1}$, Hui Guo ${ }^{1}$, Zeming Liu ${ }^{1}$ \\ and Tao Huang ${ }^{1}$ \\ ${ }^{1}$ Department of Breast and Thyroid Surgery, Union Hospital, Tongji Medical College, Huazhong University of Science and \\ Technology, Wuhan 430022, China \\ "These authors have contributed equally to this work \\ Correspondence to: Tao Huang, email: huangtaowhunion@163.com \\ Zeming Liu, email: 6myt@163.com
}

Keywords: oxyphilic thyroid carcinoma; prognosis; SEER; PSM

Received: July 18, $2017 \quad$ Accepted: August 09, 2017

Published: September 08, 2017

Copyright: Xiong et al. This is an open-access article distributed under the terms of the Creative Commons Attribution License 3.0 (CC BY 3.0), which permits unrestricted use, distribution, and reproduction in any medium, provided the original author and source are credited.

\section{ABSTRACT}

There is controversy regarding the prognosis of patients with oxyphilic thyroid cancer (OXTC). The present study compared the prognoses of OXTC, papillary thyroid cancer (PTC), and follicular thyroid cancer (FTC), in order to provide a new perspective regarding the treatment guidelines for these diseases. We evaluated data from patients with thyroid cancer who were included in the Surveillance, Epidemiology, and End Results database between 2004 and 2013. Patient mortality was evaluated using Cox proportional hazards regression analyses and Kaplan-Meier analyses with log-rank tests. The multivariate Cox regression analysis revealed that the cancerspecific survival rate for OXTC was similar to that for PTC, but higher than that for FTC. However, after propensity score matching for relevant factors, the cancer-specific survival rate for OXTC was higher than that for PTC and FTC. This unexpected result provides new implications for the treatment of patients with OXTC.

\section{INTRODUCTION}

The incidence of thyroid cancer has risen rapidly during recent decades [1-3]. Papillary thyroid cancer (PTC) and follicular thyroid cancer (FTC) (i.e., differentiated thyroid cancer) account for $>90 \%$ of all thyroid malignancies and are the most common types of thyroid carcinoma $[1,4,5]$. However, there are other rare histological variants of thyroid cancer, such as tall cell, solid, or oxyphilic thyroid cancer (OXTC) [6-8]. OXTC is also known as Hurthle cell carcinoma, and only accounts for $2-5 \%$ of all thyroid cancers [9-11]. The current World Health Organization classification system has defined OXTC as a variant of FTC, although Ganly et al. have reported that OXTC may be distinct from PTC and FTC, based on the unique genetic features of OXTC [12]. Moreover, given the rarity of OXTC, few studies have evaluated its clinical characteristics and optimal treatment [11]. The present study compared the prognoses (cancerspecific and all-cause mortality) of OXTC, PTC, and FTC, using data from the Surveillance, Epidemiology, and End Results (SEER) database (2004-2013) and propensity score matching (PSM).

\section{RESULTS}

Demographic and clinical features

This study evaluated data from 101,443 patients with thyroid cancer, including 2,615 patients with OXTC, 92,963 patients with PTC, and 5,865 patients with FTC. The patients' mean age and follow-up duration according to histological subtype are shown in Table 1. Patients with OXTC were significantly older, compared to patients with PTC or FTC. 
Table 1: Characteristics for Patients with different histological types

\begin{tabular}{|c|c|c|c|c|c|c|}
\hline \multirow[b]{2}{*}{ Covariate } & \multirow[b]{2}{*}{ level } & \multicolumn{5}{|c|}{ Histological types } \\
\hline & & $\begin{array}{c}\text { OXTC } \\
(n=2615)\end{array}$ & PTC $(n=92963)$ & P value & FTC $(n=5865)$ & P value \\
\hline Age (year) & & $57.69 \pm 15.68$ & $49.36 \pm 15.29$ & $<0.001$ & $51.33 \pm 17.20$ & $<0.001$ \\
\hline \multirow[t]{2}{*}{ Sex } & Female & $1813(69.3 \%)$ & $71785(77.2 \%)$ & $<0.001$ & $4137(70.5 \%)$ & 0.262 \\
\hline & Male & $802(30.7 \%)$ & $21178(22.8 \%)$ & & $1728(29.5 \%)$ & \\
\hline \multirow[t]{3}{*}{ Race } & White & $2201(85.1 \%)$ & $76038(82.9 \%)$ & $<0.001$ & $4529(78.3 \%)$ & $<0.001$ \\
\hline & Black & $222(8.6 \%)$ & $5704(6.2 \%)$ & & $695(12.0 \%)$ & \\
\hline & Other & $164(6.3 \%)$ & $9987(10.9 \%)$ & & $558(9.7 \%)$ & \\
\hline \multirow[t]{4}{*}{ T stage } & $\mathrm{T} 1$ & $615(25.0 \%)$ & $55606(62.2 \%)$ & $<0.001$ & $1283(23.8 \%)$ & $<0.001$ \\
\hline & $\mathrm{T} 2$ & $868(35.4 \%)$ & $13811(15.5 \%)$ & & $2174(40.2 \%)$ & \\
\hline & $\mathrm{T} 3$ & $838(34.1 \%)$ & $16407(18.4 \%)$ & & $1747(32.4 \%)$ & \\
\hline & $\mathrm{T} 4$ & $135(5.5 \%)$ & $3463(3.9 \%)$ & & $194(3.6 \%)$ & \\
\hline \multirow[t]{2}{*}{ N-stage } & N0 & $2355(95.2 \%)$ & $69465(79.0 \%)$ & $<0.001$ & $5370(97.0 \%)$ & $<0.001$ \\
\hline & N1 & $120(4.8 \%)$ & $18460(21.0 \%)$ & & $168(3.0 \%)$ & \\
\hline \multirow[t]{2}{*}{ M-stage } & M0 & $2453(96.6 \%)$ & $89658(98.8 \%)$ & $<0.001$ & $5377(94.2 \%)$ & $<0.001$ \\
\hline & M1 & $87(3.4 \%)$ & $1132(1.2 \%)$ & & $329(5.8 \%)$ & \\
\hline \multirow[t]{2}{*}{ Multifocality } & No & $2033(82.3 \%)$ & $52324(58.3 \%)$ & $<0.001$ & $4735(85.6 \%)$ & $<0.001$ \\
\hline & Yes & $438(17.7 \%)$ & $37350(41.7 \%)$ & & $797(14.4 \%)$ & \\
\hline \multirow[t]{2}{*}{ Extension } & No & $2222(87.1 \%)$ & 75994(83.7\%) & $<0.001$ & $5114(90.5 \%)$ & $<0.001$ \\
\hline & Yes & $329(12.9 \%)$ & $14847(16.3 \%)$ & & $539(9.5 \%)$ & \\
\hline \multirow[t]{3}{*}{ Radiation } & None or refused & $1094(42.9 \%)$ & $46761(51.5 \%)$ & $<0.001$ & $2573(45.0 \%)$ & 0.109 \\
\hline & $\begin{array}{c}\text { Radiation Beam } \\
\text { or Rdioactive } \\
\text { implants }\end{array}$ & $94(3.7 \%)$ & $1705(1.9 \%)$ & & $177(3.1 \%)$ & \\
\hline & $\begin{array}{l}\text { Radioisotopes } \\
\text { or Radiation } \\
\text { beam plus } \\
\text { isotopes or } \\
\text { implants }\end{array}$ & $1364(53.4 \%)$ & $42296(46.6 \%)$ & & $2970(51.9 \%)$ & \\
\hline \multirow[t]{3}{*}{ Surgery } & Lobectomy & $469(18.9 \%)$ & $12688(14.2 \%)$ & $<0.001$ & $1300(23.6 \%)$ & $<0.001$ \\
\hline & $\begin{array}{c}\text { Subtotal or } \\
\text { near-total } \\
\text { thyroidectomy }\end{array}$ & $147(5.9 \%)$ & $3337(3.7 \%)$ & & $303(5.5 \%)$ & \\
\hline & $\begin{array}{l}\text { Total } \\
\text { thyroidectomy }\end{array}$ & $1871(75.2 \%)$ & $73162(82.1 \%)$ & & $3911(70.9 \%)$ & \\
\hline $\begin{array}{l}\text { Survival } \\
\text { months (month) }\end{array}$ & & $53.90 \pm 34.45$ & $49.09 \pm 33.76$ & $<0.001$ & $53.12 \pm 34.33$ & 0.331 \\
\hline
\end{tabular}

OXTC: Oxyphilic thyroid adenocarcinoma; PTC: papillary thyroid cancer; FTC: follicular thyroid carcinoma. 
Table 2: Hazard Ratios of different histological types for the cancer specific deaths and all cause deaths of thyroid cancer

\begin{tabular}{|c|c|c|c|c|c|c|c|c|}
\hline \multirow{2}{*}{$\begin{array}{l}\text { Histological } \\
\text { types }\end{array}$} & $\begin{array}{l}\text { Cancer- } \\
\text { Specific } \\
\text { Deaths, }\end{array}$ & \%) & $\begin{array}{c}\text { Cancer- } \\
\text { Specific Deaths } \\
\text { per }\end{array}$ & \multirow{2}{*}{$95 \%$ CI } & $\begin{array}{l}\text { All Cause } \\
\text { Deaths, }\end{array}$ & \multirow{2}{*}{$\%$} & $\begin{array}{l}\text { All Cause } \\
\text { Deaths per }\end{array}$ & \multirow{2}{*}{$95 \%$ CI } \\
\hline & No. & & $\begin{array}{c}\text { 1,000 Person- } \\
\text { Years }\end{array}$ & & No. & & $\begin{array}{c}\text { 1,000 Person- } \\
\text { Years }\end{array}$ & \\
\hline OXTC & 101 & 3.86 & 8.343 & $\begin{array}{l}6.844- \\
10.169\end{array}$ & 319 & 12.19 & 26.646 & $23.852-29.768$ \\
\hline PTC & 966 & 1.04 & 2.403 & $2.252-2.564$ & 4388 & 4.72 & 11.068 & $10.739-11.408$ \\
\hline FTC & 190 & 3.24 & 6.509 & $5.598-7.569$ & 538 & 9.17 & 19.337 & $17.717-21.104$ \\
\hline
\end{tabular}

OXTC: Oxyphilic thyroid adenocarcinoma; PTC: papillary thyroid cancer; FTC: follicular thyroid carcinoma.

\section{Cancer-specific and all-cause mortality rates}

During the follow-up period, cancer-specific death was detected for 101 patients in the OXTC group, 996 patients in the PTC group, and 190 patients in the FTC group. The cancer-specific mortality rates per 1,000 person-years were $8.343(95 \%$ confidence interval [CI]: 6.844-10.169) for OXTC, 2.403 (95\% CI: 2.252-2.564) for PTC, and 6.509 (95\% CI: 5.598-7.569) for FTC (Table 2). In addition, during the follow-up period, all-cause death was detected for 319 patients in the OXTC group, 4,388 patients in the PTC group, and 538 patients in the FTC group. The all-cause mortality rates per 1,000 personyears were 26.646 (95\% CI: 23.852-29.768) for OXTC, 11.068 (95\% CI: $10.739-11.408)$ for PTC, and 19.337 (95\% CI: 17.717-21.104) for FTC (Table 2).

\section{Risk factors for cancer-specific and all-cause mortality}

The univariate Cox regression analyses revealed that cancer-specific mortality was associated with age, sex, race, histological type, TNM stage, extension, radiation treatment, and surgical approach. The multivariate Cox regression model revealed that PTC was an independent risk factor for cancer-specific mortality, compared to OXTC (Table 3). The univariate Cox regression analyses revealed that all-cause mortality was associated with age, sex, race, histological type, TNM stage, multifocality, extension, radiation treatment, and surgical approach. The multivariate Cox regression model revealed that PTC was also an independent risk factor for all-cause mortality, compared to OXTC (Table 3).

\section{Adjusting for patient characteristics using PSM}

The cancer-specific and all-cause mortality rates were significantly different when we compared OXTC to PTC and FTC (both $p<0.001$, Figure 1A-1D). Thus, to minimize selection bias, PSM was performed for age, sex, race, TNM stage, multifocality, extension, and radiation treatment. After PSM for age, sex, and race, OXTC was associated with a lower cancer-specific mortality rate, compared to PTC $(p<0.001)$ and FTC $(p=0.005)$ (Figure 2A, 2B). After PSM for age, sex, race, TNM stage, multifocality, and extension, OXTC was still associated with a significantly lower cancer-specific mortality rate, compared to PTC $(p<0.001)$ and FTC $(p=0.005)$ (Figure $3 \mathrm{~A}, 3 \mathrm{~B}$ ). After PSM for all relevant factors and radiation and surgery treatment, the cancer-specific mortality rate for OXTC remained significantly lower than that for PTC $(\mathrm{p}<0.001)$ and FTC $(\mathrm{p}=0.01)$ (Figure 4A, 4B).

After PSM for age, sex, and race, OXTC was associated with a lower all-cause mortality rate, compared to PTC and FTC (both $p<0.001$, Figure 5A, 5B). Similar results were obtained after PSM for age, sex, race, TNM stage, multifocality, and extension (Figure 6A, 6B). After PSM for all relevant factors and radiation and surgery treatment, OXTC was associated with a lower all-cause mortality rate, compared to PTC $(\mathrm{p}<0.001)$ and FTC ( $\mathrm{p}=$ 0.003) (Figure 7A, 7B).

\section{DISCUSSION}

Oxyphilic thyroid tumors (Hurthle cell tumors) include Hurthle cell adenoma, Hurthle cell thyroid carcinoma, and Hurthle cell papillary thyroid carcinoma. The oxyphilic cells exhibit various features, such as a finely granular eosinophilic cytoplasm and an increased number of mitochondria in the thyroid ultrastructure [13]. However, given the rarity of thyroid malignancies, little is known regarding the long-term survival of patients with OXTC, and conflicting results have been reported in the limited number of single-center studies, which had relatively small samples sizes [14-17].

In contrast, the SEER database identifies and tracks patients from diverse geographic regions, and is considered the gold standard database for tumor surveillance and survival analysis in the US, as it contains 
Table 3: Risk factors for survival: outcome of thyroid cancer specific mortality and all-cause mortality

\begin{tabular}{|c|c|c|c|c|c|c|c|c|c|}
\hline \multirow{3}{*}{ Covariate } & \multirow{3}{*}{ level } & \multicolumn{4}{|c|}{ Thyroid Cancer specific mortality } & \multicolumn{4}{|c|}{ All cause mortality } \\
\hline & & \multicolumn{2}{|c|}{ Univariate Cox regression } & \multicolumn{2}{|c|}{$\begin{array}{l}\text { Multivariate Cox } \\
\text { regression }\end{array}$} & \multicolumn{2}{|c|}{ Univariate Cox regression } & \multicolumn{2}{|c|}{$\begin{array}{l}\text { Multivariate Cox } \\
\text { regression }\end{array}$} \\
\hline & & $\begin{array}{c}\text { Hazard Ratio }(95 \% \\
\text { CI) }\end{array}$ & p-value & $\begin{array}{l}\text { Hazard Ratio } \\
(95 \% \text { CI })\end{array}$ & p-value & $\begin{array}{l}\text { Hazard Ratio } \\
\text { (95\% CI) }\end{array}$ & p-value & $\begin{array}{l}\text { Hazard Ratio } \\
\text { (95\% CI) }\end{array}$ & p-value \\
\hline Age & & $1.097(1.093-1.102)$ & $<0.001$ & $\begin{array}{l}1.067(1.061- \\
1.072)\end{array}$ & $<0.001$ & $\begin{array}{c}1.087(1.085- \\
1.089)\end{array}$ & $<0.001$ & $\begin{array}{c}1.077(1.074- \\
1.080)\end{array}$ & $<0.001$ \\
\hline \multirow[t]{2}{*}{ Sex } & Female & ref & & ref & & ref & & ref & \\
\hline & Male & $2.673(2.392-2.988)$ & $<0.001$ & $\begin{array}{c}1.332(1.143- \\
1.553)\end{array}$ & $<0.001$ & $\begin{array}{l}2.439(2.308- \\
2.576)\end{array}$ & $<0.001$ & $\begin{array}{l}1.634(1.526- \\
1.750)\end{array}$ & $<0.001$ \\
\hline \multirow[t]{3}{*}{ Race } & White & ref & & ref & & ref & & ref & \\
\hline & Black & $1.075(0.860-1.343)$ & 0.525 & $\begin{array}{c}1.147(0.826- \\
1.591)\end{array}$ & 0.413 & $\begin{array}{l}1.286(1.165- \\
1.420)\end{array}$ & $<0.001$ & $\begin{array}{l}1.426(1.261- \\
1.612)\end{array}$ & $<0.001$ \\
\hline & Other & $1.428(1.217-1.675)$ & $<0.001$ & $\begin{array}{l}0.921(0.735- \\
1.154)\end{array}$ & 0.473 & $\begin{array}{l}0.941(0.858- \\
1.032)\end{array}$ & 0.199 & $\begin{array}{l}0.802(0.710- \\
0.906)\end{array}$ & $<0.001$ \\
\hline \multirow[t]{3}{*}{ Histological types } & OXTC & ref & & ref & & ref & & ref & \\
\hline & PTC & $0.288(0.234-0.353)$ & $<0.001$ & $\begin{array}{l}0.787(0.583- \\
1.063)\end{array}$ & 0.118 & $\begin{array}{l}0.423(0.377- \\
0.474)\end{array}$ & $<0.001$ & $\begin{array}{l}0.811(0.701- \\
0.938)\end{array}$ & 0.005 \\
\hline & FTC & $0.850(0.668-1.082)$ & 0.186 & $\begin{array}{c}1.489(1.056- \\
2.099)\end{array}$ & 0.023 & $\begin{array}{l}0.763(0.664- \\
0.876)\end{array}$ & $<0.001$ & $\begin{array}{c}1.020(0.858- \\
1.212)\end{array}$ & 0.824 \\
\hline \multirow[t]{4}{*}{ T-stage T-stage } & $\mathrm{T} 1$ & ref & & ref & & ref & & ref & \\
\hline & $\mathrm{T} 2$ & $2.807(2.123-3.712)$ & $<0.001$ & $\begin{array}{l}2.020(1.445- \\
2.823)\end{array}$ & $<0.001$ & $\begin{array}{c}1.128(1.033- \\
1.232)\end{array}$ & 0.007 & $\begin{array}{c}1.104(0.997- \\
1.224)\end{array}$ & 0.058 \\
\hline & $\mathrm{T} 3$ & $8.251(6.609-10.300)$ & $<0.001$ & $\begin{array}{l}3.789(2.705- \\
5.307)\end{array}$ & $<0.001$ & $\begin{array}{l}1.683(1.561- \\
1.814)\end{array}$ & $<0.001$ & $\begin{array}{c}1.220(1.072- \\
1.388)\end{array}$ & 0.003 \\
\hline & $\mathrm{T} 4$ & $\begin{array}{l}86.971(70.791- \\
106.849)\end{array}$ & $<0.001$ & $\begin{array}{l}13.626(9.256- \\
20.058)\end{array}$ & $<0.001$ & $\begin{array}{l}7.737(7.160- \\
8.361)\end{array}$ & $<0.001$ & $\begin{array}{l}2.723(2.285- \\
\quad 3.244)\end{array}$ & $<0.001$ \\
\hline \multirow[t]{2}{*}{$\mathrm{N}$ stage } & No & ref & & ref & & ref & & ref & \\
\hline & N1 & $4.533(4.011-5.123)$ & $<0.001$ & $\begin{array}{l}2.128(1.782- \\
2.541)\end{array}$ & $<0.001$ & $\begin{array}{c}1.635(1.532- \\
1.746)\end{array}$ & $<0.001$ & $\begin{array}{c}1.542(1.408- \\
1.689)\end{array}$ & $<0.001$ \\
\hline \multirow[t]{2}{*}{ M-stage } & M0 & ref & & ref & & ref & & ref & \\
\hline & M1 & $\begin{array}{l}49.059(43.578- \\
55.229)\end{array}$ & $<0.001$ & $\begin{array}{l}6.345(5.282- \\
7.621)\end{array}$ & $<0.001$ & $\begin{array}{l}13.482(12.423- \\
14.631)\end{array}$ & $<0.001$ & $\begin{array}{l}3.730(3.272- \\
4.251)\end{array}$ & $<0.001$ \\
\hline \multirow[t]{2}{*}{ Multifocality } & No & ref & & ref & & ref & & ref & \\
\hline & Yes & $0.883(0.777-1.002)$ & 0.055 & $\begin{array}{l}0.782(0.670- \\
0.914)\end{array}$ & 0.002 & $\begin{array}{l}0.862(0.812- \\
0.915)\end{array}$ & $<0.001$ & $\begin{array}{c}0.962(0.897- \\
1.033)\end{array}$ & 0.290 \\
\hline \multirow[t]{2}{*}{ Extension } & No & ref & & ref & & ref & & ref & \\
\hline & Yes & $\begin{array}{l}12.707(11.172- \\
14.452)\end{array}$ & $<0.001$ & $\begin{array}{l}1.517(1.124- \\
2.049)\end{array}$ & 0.007 & $\begin{array}{l}2.634(2.480- \\
2.798)\end{array}$ & $<0.001$ & $\begin{array}{c}1.093(0.946- \\
1.264)\end{array}$ & 0.228 \\
\hline \multirow[t]{3}{*}{ Radiation } & None or refused & ref & & ref & & ref & & ref & \\
\hline & $\begin{array}{l}\text { Radiation Beam or } \\
\text { Rdioactive implants }\end{array}$ & $\begin{array}{l}14.719(12.728- \\
17.022)\end{array}$ & $<0.001$ & $\begin{array}{l}2.754(2.185- \\
\quad 3.472)\end{array}$ & $<0.001$ & $\begin{array}{l}3.594(3.247- \\
3.979)\end{array}$ & $<0.001$ & $\begin{array}{c}1.409(1.212- \\
1.638)\end{array}$ & $<0.001$ \\
\hline & $\begin{array}{l}\text { Radioisotopes or } \\
\text { Radiation beam+ } \\
\text { isotopes/implants }\end{array}$ & $0.895(0.787-1.018)$ & 0.91 & $\begin{array}{c}0.814(0.679- \\
0.976)\end{array}$ & 0.026 & $\begin{array}{l}0.580(0.546- \\
0.615)\end{array}$ & $<0.001$ & $\begin{array}{c}0.693(0.643- \\
0.748)\end{array}$ & $<0.001$ \\
\hline \multirow[t]{3}{*}{ Surgery } & Lobectomy & ref & & ref & & ref & & ref & \\
\hline & $\begin{array}{l}\text { Subtotal or near-total } \\
\text { thyroidectomy }\end{array}$ & $2.009(1.471-2.744)$ & $<0.001$ & $\begin{array}{c}1.339(0.903- \\
1.985)\end{array}$ & 0.147 & $\begin{array}{c}1.047(0.908- \\
1.209)\end{array}$ & 0.527 & $\begin{array}{l}1.047(0.890- \\
1.230)\end{array}$ & 0.581 \\
\hline & Total thyroidectomy & $1.332(1.087-1.633)$ & 0.006 & $\begin{array}{c}1.127(0.868- \\
1.462)\end{array}$ & 0.370 & $\begin{array}{c}0.803(0.743- \\
0.869)\end{array}$ & $<0.001$ & $\begin{array}{l}0.960(0.875- \\
1.052)\end{array}$ & 0.381 \\
\hline
\end{tabular}

OXTC: Oxyphilic thyroid carcinoma; PTC: papillary thyroid cancer; FTC: follicular thyroid carcinoma. 
data from approximately $10 \%$ of the American patient population [18]. Therefore, the present study evaluated the prognosis of OXTC using population-based data from the SEER database.

Goffredo et al. evaluated SEER data (1998-2009) and reported that OXTC was more aggressive and had a poorer prognosis, compared to the other types of differentiated thyroid cancer [19]. However, that study did not compare the prognoses of OXTC and other thyroid cancers using PSM, and may have been limited by its inability to adjust for confounding factors.
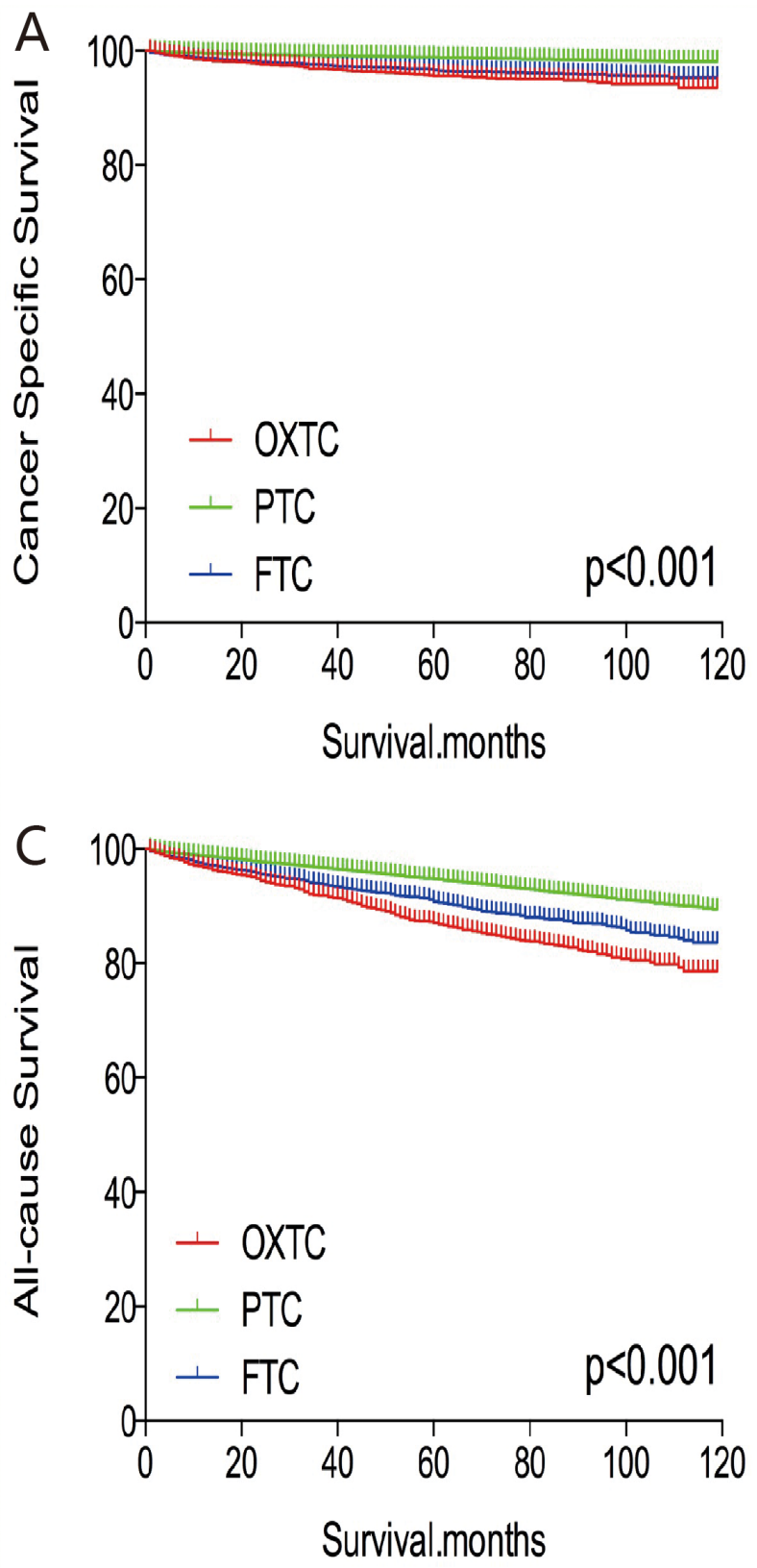

In the present study, patients with OXTC were older (57.69 years old), compared to patients with PTC and FTC. Many studies have indicated that age plays a unique prognostic role in thyroid cancer [18, 20, 21], and the present study confirmed that age was an independent risk factor for both cancer-specific and all-cause mortality. Furthermore, PSM for age, race, and sex confirmed that OXTC was associated with a better prognosis, compared to PTC and FTC. Therefore, an older age at the diagnosis of OXTC may be associated with a relatively poor prognosis.
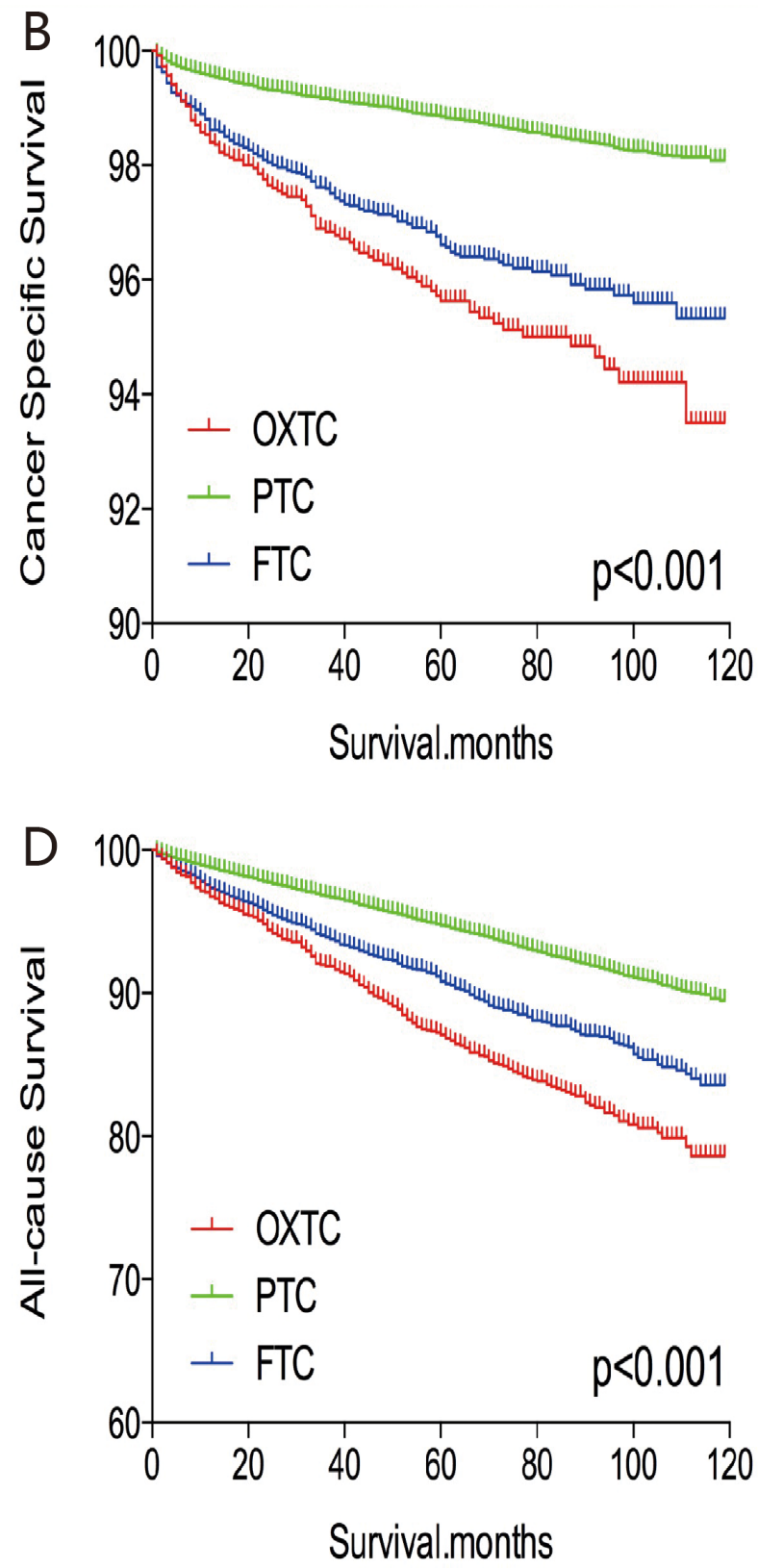

Figure 1: Kaplan Meier curves among patients stratified by subtype for cancer-specific mortality. (A, B) and all cause mortality (C, D). 
Previous reports have provided conflicting information regarding whether OXTC has more aggressive clinical features, compared to PTC or FTC [22-25]. However, it is clear that aggressive clinical characteristics (e.g., nodal metastasis, distant metastasis, and larger tumor size) are associated with more advanced disease and shorter cancer-specific survival. In the present study, PSM for demographic and clinical risk factors revealed

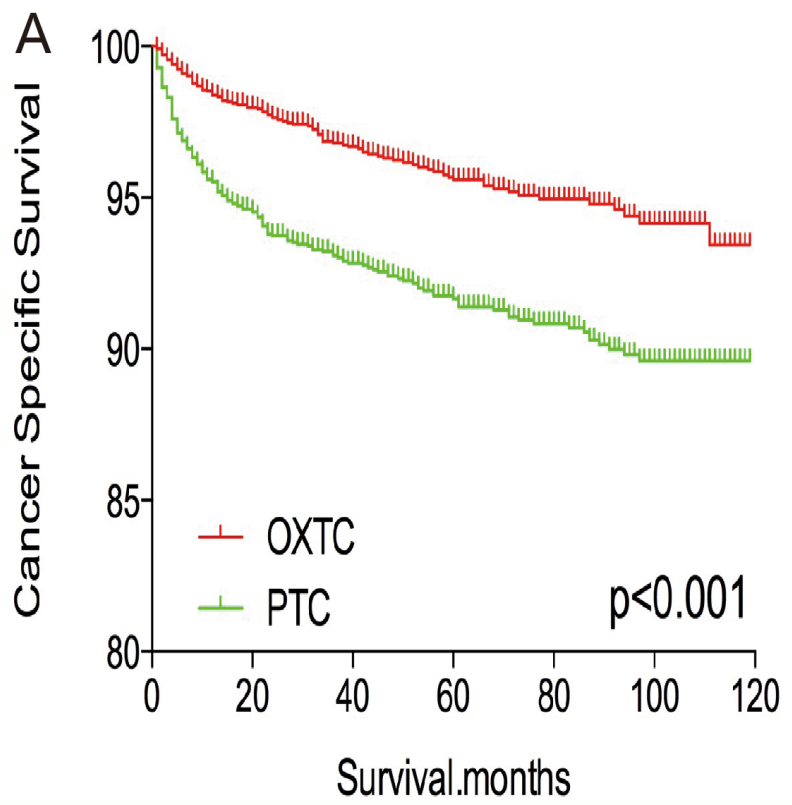

that OXTC was associated with lower cancer-specific and all-cause mortality rates, compared to PTC and FTC.

The main purpose of radioiodine (RAI) treatment after total thyroidectomy is the ablation of residual thyroid tissue, which facilitates the early detection of cancer recurrence [26]. However, the current guidelines debate the use of RAI for OXTC [11]. In the present study, patients with OXTC were more likely to receive

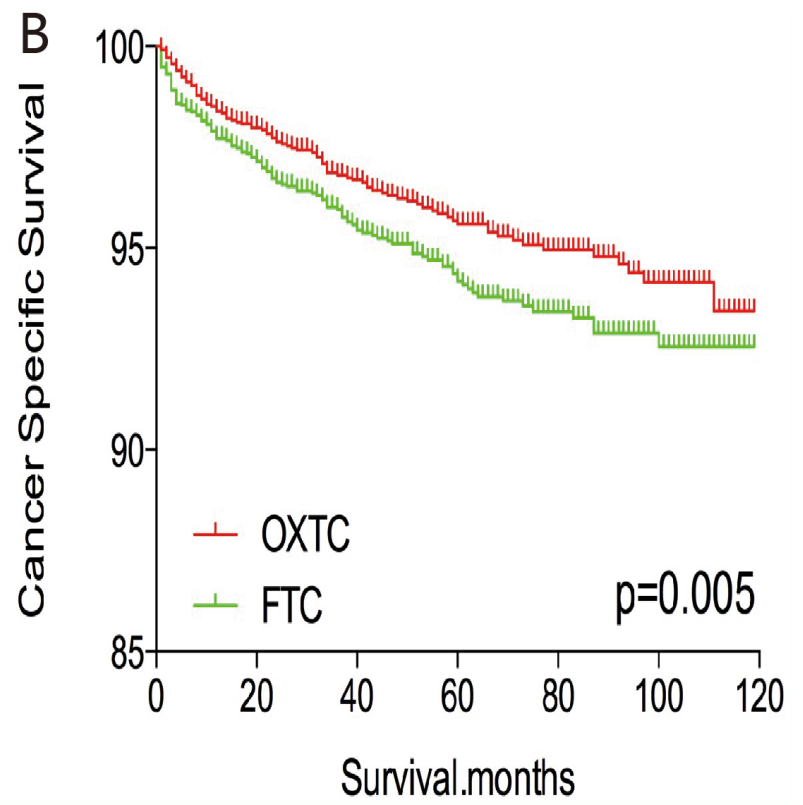

Figure 2: Kaplan Meier curves of cancer-specific mortality for matched subtype pairs. Age, sex and race matching between OXTC and PTC (A), OXTC and FTC (B).
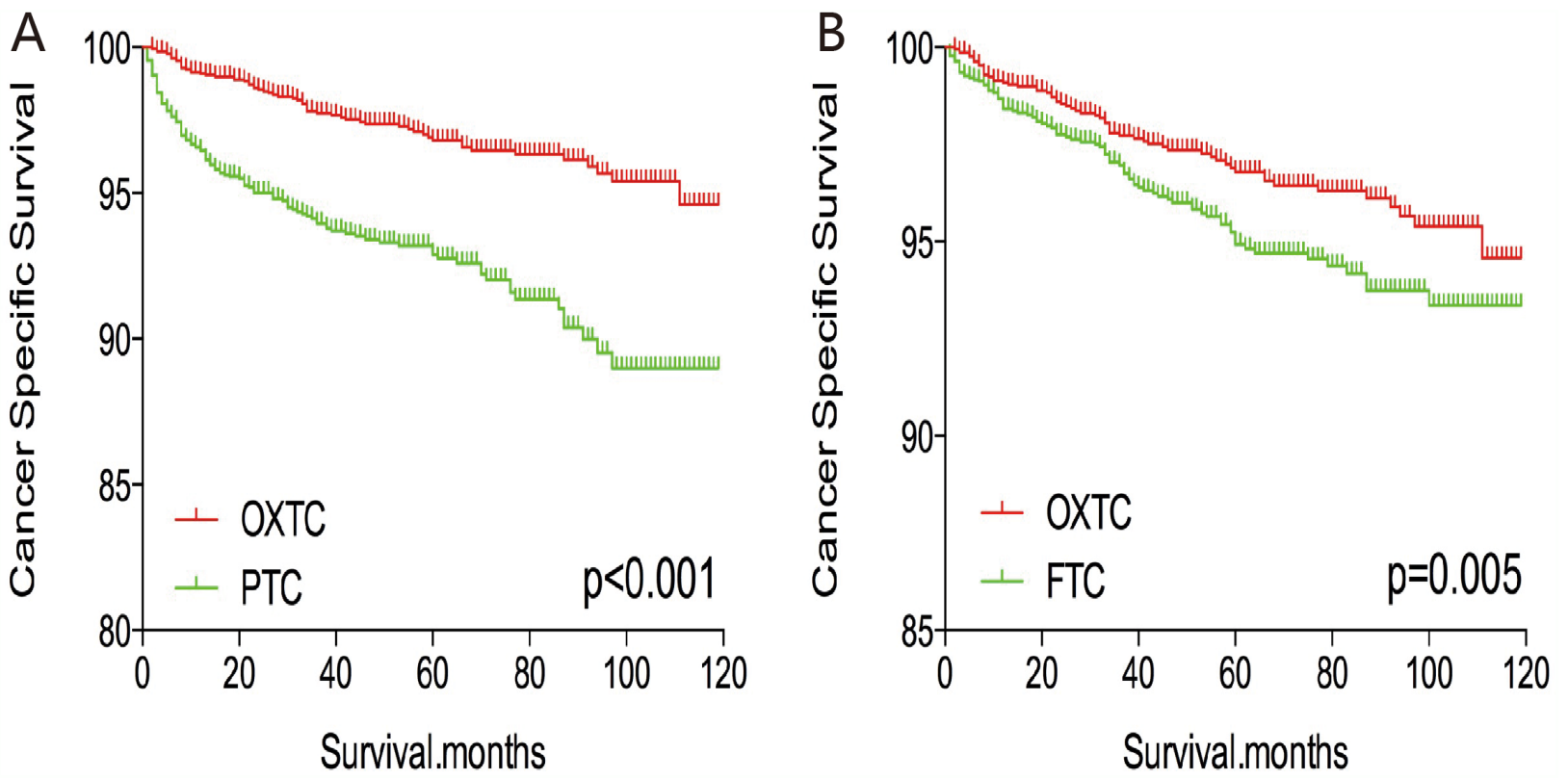

Figure 3: Kaplan Meier curves of cancer-specific mortality for matched Subtype pairs. Age, sex, race, T/N/M stage, multifocality, extension matched between OXTC and PTC (A), OXTC and FTC (B). 
RAI treatment, compared to patients with PTC and FTC, although there remains insufficient evidence regarding the effectiveness of RAI treatment in this setting.

Ganly et al. have indicated that OXTC may be a unique type of thyroid malignancy, compared to PTC and FTC, as it has unique mutational, transcriptional, cytogenetic, and gene expression changes [12]. For example, OXTC was not associated with alterations in the
BRAF, PIK3CA, or PPAR genes, and only $11.1 \%$ of OXTC cases involved $R A S$ mutations. Although the $\mathrm{Wnt} / \beta$ catenin pathway is considered highly activated in OXTC, the SEER database does not contain mutation information and we could not include genetic status in our analyses.

There are several limitations in the present study. First, the SEER database lacks information regarding recurrence and surgery-related comorbidities,
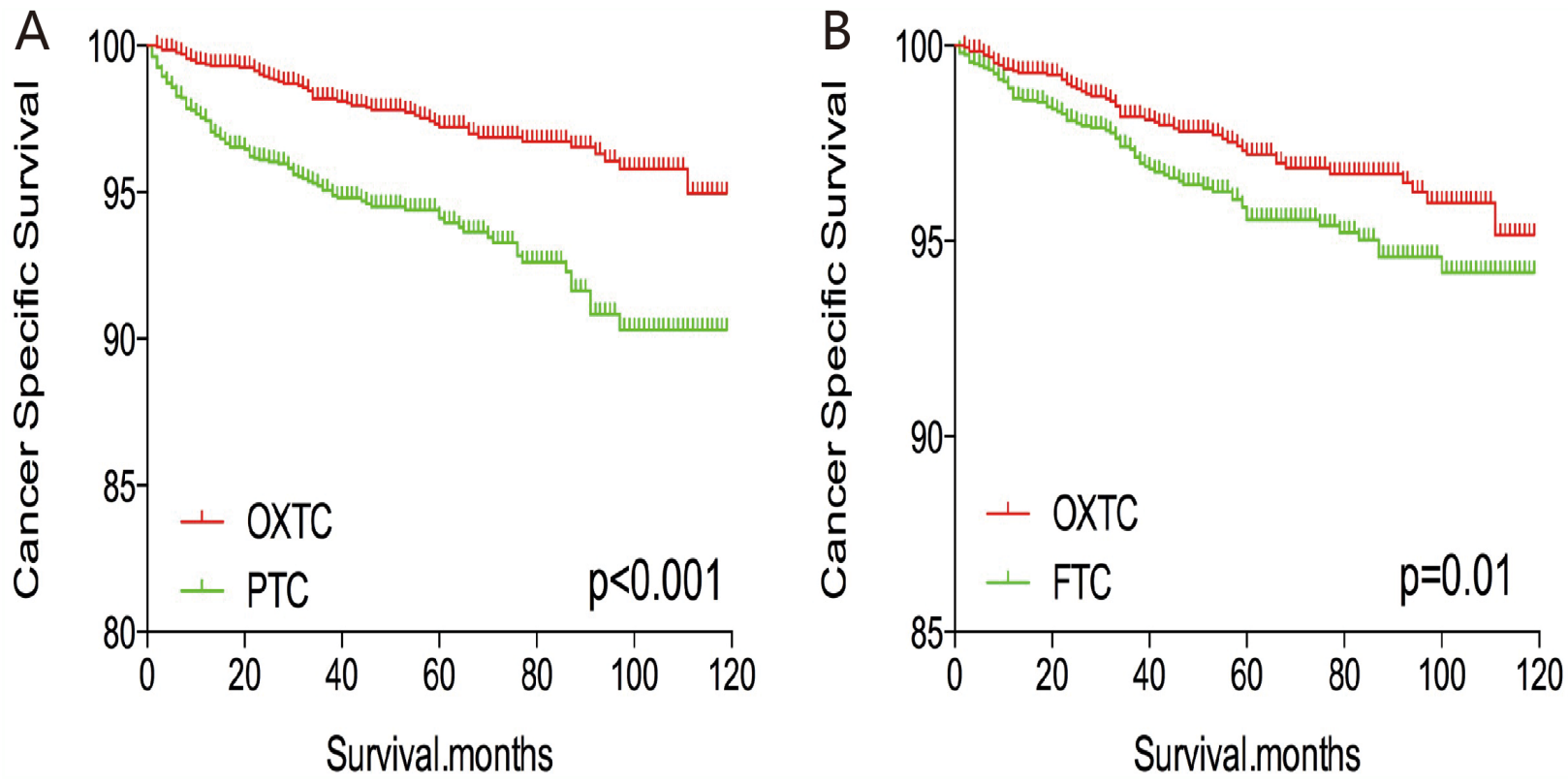

Figure 4: Kaplan Meier curves of cancer-specific mortality for matched Subtype pairs. Age, sex, race, T/N/M stage, multifocality, extension, surgery and radiation treatment matched between OXTC and PTC (A), OXTC and FTC (B).
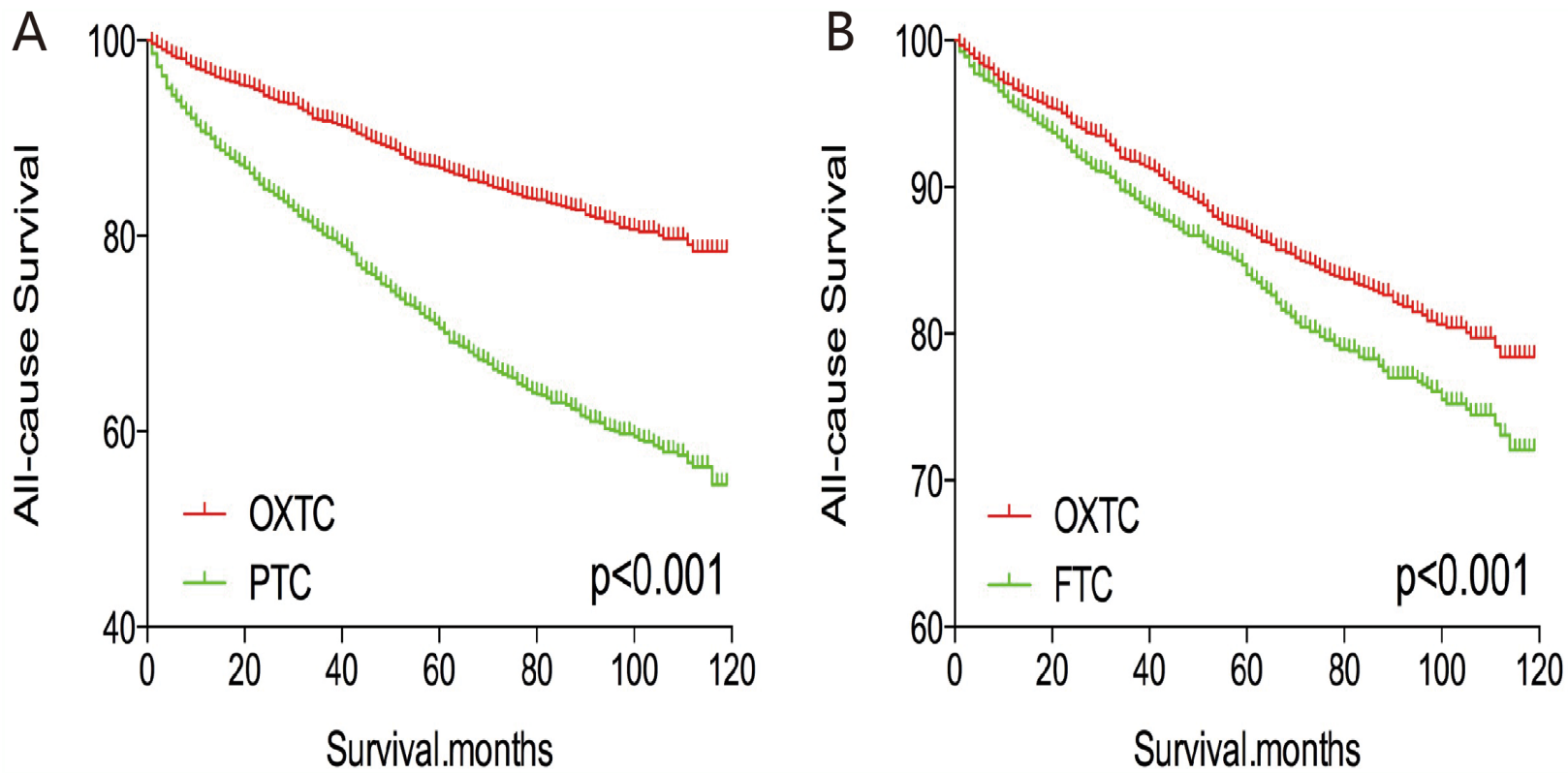

Figure 5: Kaplan Meier curves of all cause mortality for matched Subtype pairs. Age, sex and race matching between OXTC and PTC (A), OXTC and FTC (B). 
and we could not account for these factors in our analyses. Second, we did not evaluate or consider the patients' family history, vascular invasion status, accurate extension information or other histological characteristics. Third, the SEER database does not include information regarding whether the patients underwent repeat surgery, and this lack of information may have biased our findings.

In conclusion, our results indicate that patients who were diagnosed with OXTC had an unexpectedly good prognosis, compared to patients with PTC or FTC. This information may be useful for selecting appropriate treatments for these patients.
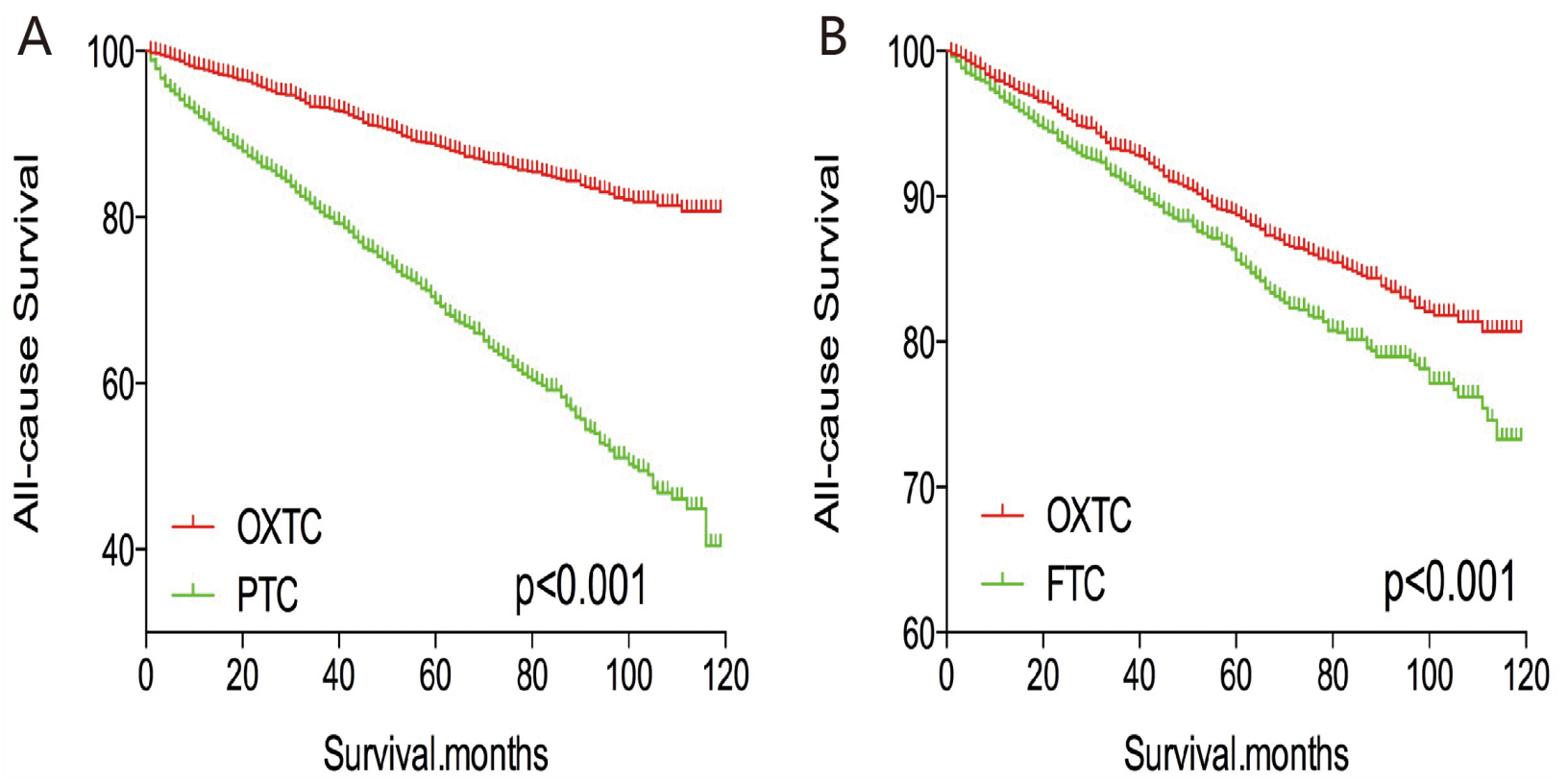

Figure 6: Kaplan Meier curves of all cause mortality for matched Subtype pairs. Age, sex, race, T/N/M stage, multifocality, extension matching between OXTC and PTC (A), OXTC and FTC (B).
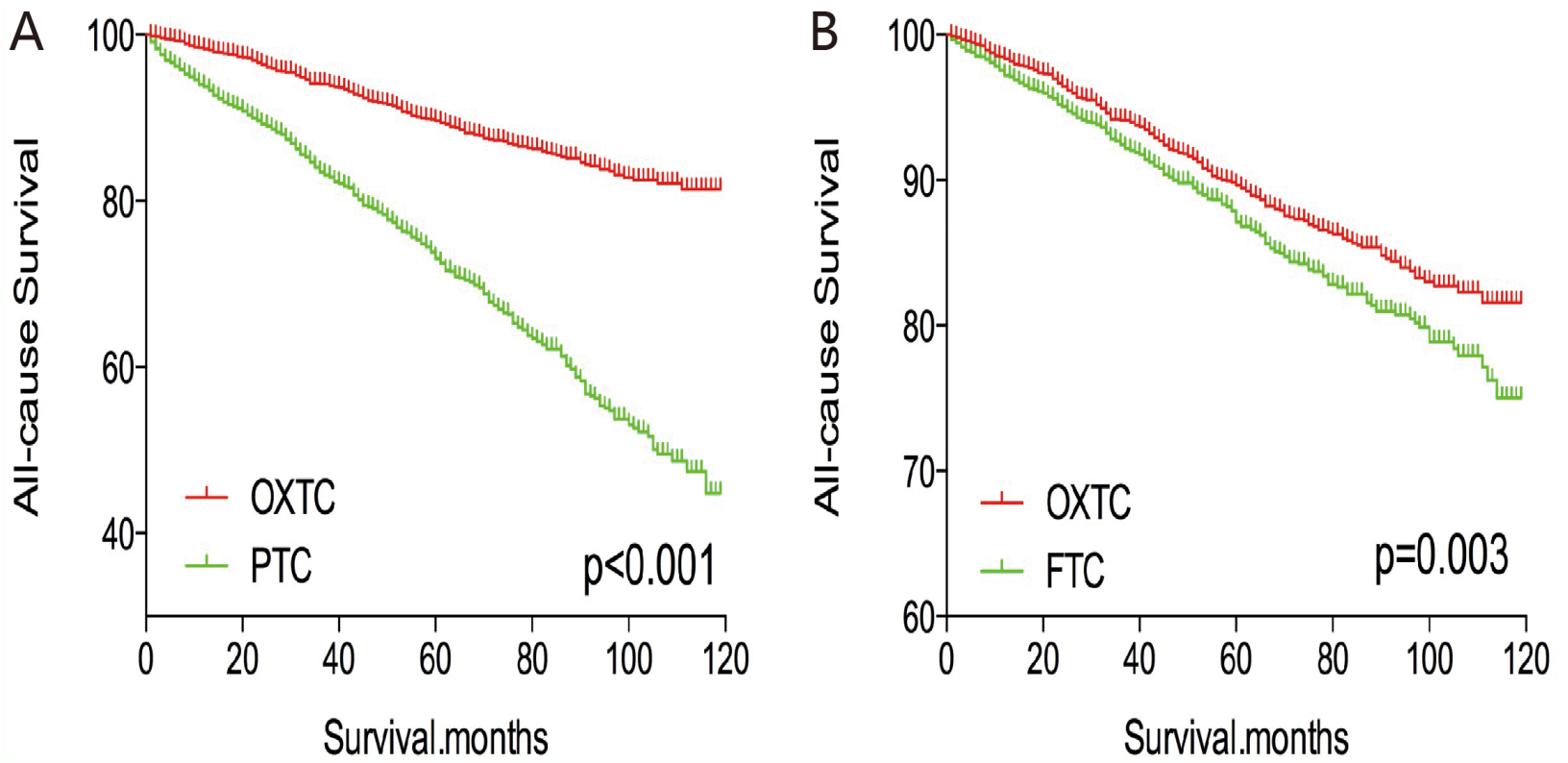

Figure 7: Kaplan Meier curves of all cause mortality for matched Subtype pairs. Age, sex, race, T/N/M stage, multifocality, extension, surgery and radiation treatment matching between OXTC and PTC (A), OXTC and FTC (B). 


\section{MATERIALS AND METHODS}

\section{Ethical considerations and data collection}

This study's retrospective protocol was approved by our institution's ethical review board and complied with the ethical standards of the Declaration of Helsinki, as well as the relevant national and international guidelines. The SEER project is an American population-based cancer registry that was launched in 1973 and is supported by the Centers for Disease Control and Prevention and the National Cancer Institute. The database contains information regarding cancer incidence, prevalence, and mortality, as well as population-based variables and primary tumor characteristics (i.e., histological subtype) from multiple geographic regions.

The present study included and evaluated SEER data (2004-2013) from patients with thyroid cancer according to their subtype (OXTC, PTC, and FTC) using code C73.9 from the International Classification of Diseases for Oncology (i.e., thyroid, papillary, and/or follicular histology). The eligible diagnostic codes were: "papillary carcinoma", "papillary adenocarcinoma", "oxyphilic adenocarcinoma", "follicular adenocarcinoma", "papillary carcinoma, follicular variant", and "papillary \& follicular adenocarcinoma". Cases without American Joint Committee on Cancer staging information (version 6) were excluded to ensure accurate analyses. Cases without information of follow up time were also excluded. The three histological subtypes were compared according to age, sex, race, TNM stage, multifocality, extension, and radiation treatment (i.e., none or refused, external beam radiation therapy, or RAI).

\section{Statistical analyses}

The quantitative variables were expressed as mean \pm standard deviation (SD), while the categorical ones were presented as percentages. Kaplan-Meier survival curves with the log-rank test were used for determination of all-cause survival and cancer-specific survival. Cox proportional hazard regression analyses were using to estimate hazard ratios and $95 \%$ CIs, in order to quantify the effects of the different histological subtypes on cancer-specific and all-cause mortality. PSM was also used to further adjust for potential baseline confounding factors. All p-values were 2-sided, and p-values $<.05$ were considered significant. Analyses were performed using SPSS version 23.0, Stata/SE version 12 (Stata Corp.), and GraphPad Prism version 6 (GraphPad Software Inc.).

\section{Abbreviations}

CPTC: classic papillary thyroid cancer; CI: confidence interval; FTC: follicular thyroid cancer;
OXTC: oxyphilic thyroid carcinoma; PSM: propensity score matching; PTC: papillary thyroid cancer; SEER: Surveillance, Epidemiology, and End Results.

\section{Author contributions}

All authors contributed to the design of the study and writing of the manuscript Y.Q.X and Q.Y.Z undertook the research and performed the analyses. All authors reviewed and approved the final version of the manuscript.

\section{CONFLICTS OF INTEREST}

The authors declare no conflicts of interest.

\section{FUNDING}

This study was supported by grants from the National Natural Science Foundation of China (grant no. $81602350)$.

\section{REFERENCES}

1. Haugen BR, Alexander EK, Bible KC, Doherty GM, Mandel SJ, Nikiforov YE, Pacini F, Randolph GW, Sawka AM, Schlumberger M, Schuff KG, Sherman SI, Sosa JA, et al. 2015 American Thyroid Association Management Guidelines for Adult Patients with Thyroid Nodules and Differentiated Thyroid Cancer The American Thyroid Association Guidelines Task Force on Thyroid Nodules and Differentiated Thyroid Cancer. Thyroid. 2016; 26: 1-133. doi: 10.1089/thy.2015.0020.

2. Simard EP, Ward EM, Siegel R, Jemal A. Cancers with increasing incidence trends in the United States: 1999 through 2008. CA Cancer J Clin. 2012; 62: 118-28. doi: 10.3322/caac.20141.

3. Liu ZM, Zeng W, Chen TW, Guo YW, Zhang C, Liu CP, Huang T. A comparison of the clinicopathological features and prognoses of the classical and the tall cell variant of papillary thyroid cancer: a meta-analysis. Oncotarget. 2017; 8: 6222-32. doi: 10.18632/oncotarget.14055.

4. Mao YS, Xing MZ. Recent incidences and differential trends of thyroid cancer in the USA. Endocrine-Related Cancer. 2016; 23: 313-22. doi: 10.1530/erc-15-0445.

5. Xing MZ, Haugen BR, Schlumberger M. Progress in molecular-based management of differentiated thyroid cancer. Lancet. 2013; 381: 1058-69.

6. Morandi L, Righi A, Maletta F, Rucci P, Pagni F, Gallo M, Rossi S, Caporali L, Sapino A, Lloyd RV, Asioli S. Somatic mutation profiling of hobnail variant of papillary thyroid carcinoma. Endocrine-Related Cancer. 2017; 24: 107-17. doi: 10.1530/erc-16-0546.

7. Chang H, Kim SM, Chun KW, Kim BW, Lee YS, Chang HS, Hong SW, Park CS. Clinicopathologic features of solid 
variant papillary thyroid cancer. Anz Journal of Surgery. 2014; 84: 380-2. doi: 10.1111/ans. 12307.

8. Lee J, Ham S, Lee MH, Kim SJ, Park JH, Lee SE, Chang JY, Joung KH, Kim TY, Kim JM, Sul HJ, Kweon GR, Jo YS, et al. Dysregulation of Parkin-mediated mitophagy in thyroid Hurthle cell tumors. Carcinogenesis. 2015; 36: 1407-18. doi: 10.1093/carcin/bgv122.

9. Lim H, Devesa SS, Sosa JA, Check D, Kitahara CM. Trends in Thyroid Cancer Incidence and Mortality in the United States, 1974-2013. JAMA. 2017; 317: 1338-48. doi: 10.1001/jama.2017.2719.

10. Fagin JA, Wells SA. Biologic and Clinical Perspectives on Thyroid Cancer. New England Journal of Medicine. 2016; 375: 1054-67. doi: 10.1056/NEJMra1501993.

11. Oluic B, Paunovic I, Loncar Z, Djukic V, Diklic A, Jovanovic M, Garabinovic Z, Slijepcevic N, Rovcanin B, Micic D, Filipovic A, Zivaljevic V. Survival and prognostic factors for survival, cancer specific survival and disease free interval in 239 patients with Hurthle cell carcinoma: a single center experience. Bmc Cancer. 2017; 17: 11. doi: 10.1186/s12885-017-3370-x.

12. Ganly I, Ricarte J, Eng S, Ghossein R, Morris LG, Liang YP, Socci N, Kannan K, Mo QX, Fagin JA, Chan TA. Genomic Dissection of Hurthle Cell Carcinoma Reveals a Unique Class of Thyroid Malignancy. Journal of Clinical Endocrinology \& Metabolism. 2013; 98: E962-E72. doi: 10.1210/jc.2012-3539.

13. Allia E, Cassoni P, Marrocco T, Volante M, Bussolati B, Wong M, Clark OH, Papotti M. Oxyphilic and nonoxyphilic thyroid carcinoma cell lines differ in expressing apoptosis-related genes. Journal of Endocrinological Investigation. 2003; 26: 660-7.

14. Khafif A, Khafif RA, Attie JN. Hurthle cell carcinoma: A malignancy of low-grade potential. Head and Neck. 1999; 21: 506-11.

15. Stojadinovic A, Ghossein RA, Hoos A, Urist MJ, Spiro RH, Shah JP, Brennan MF, Shaha AR, Singh B. Hurthle cell carcinoma: A critical histopathologic appraisal. Journal of Clinical Oncology. 2001; 19: 2616-25.

16. Nagar S, Aschebrook-Kilfoy B, Kaplan EL, Angelos P, Grogan RH. Hurthle cell carcinoma: An update on survival over the last 35 years. Surgery. 2013; 154: 1263-71. doi: 10.1016/j.surg.2013.06.029.
17. Kushchayeva Y, Duh QY, Kebebew E, D'Avanzo A, Clark $\mathrm{OH}$. Comparison of clinical characteristics at diagnosis and during follow-up in 118 patients with Hurthle cell or follicular thyroid cancer. American Journal of Surgery. 2008; 195: 457-62. doi: 10.1016/j.amjsurg.2007.06.001.

18. Adam MA, Thomas S, Hyslop T, Scheri RP, Roman SA, Sosa JA. Exploring the Relationship Between Patient Age and Cancer-Specific Survival in Papillary Thyroid Cancer: Rethinking Current Staging Systems. Journal of Clinical Oncology. 2016; 34: 4415-4420. doi: 10.1200/ jco.2016.68.9372.

19. Goffredo P, Roman SA, Sosa JA. Hurthle Cell Carcinoma A Population-Level Analysis of 3311 Patients. Cancer. 2013; 119: 504-11. doi: 10.1002/cncr.27770.

20. Shi RL, Qu N, Liao T, Wei WJ, Wang YL, Ji QH. The Trend of Age-Group Effect on Prognosis in Differentiated Thyroid Cancer. Scientific Reports. 2016; 6: 8. doi: 10.1038/ srep27086.

21. Lundgren CI, Hall P, Ekbom A, Frisell J, Zedenius J, Dickman PW. Incidence and survival of Swedish patients with differentiated thyroid cancer. International Journal of Cancer. 2003; 106: 569-73. doi: 10.1002/ijc.11275.

22. Ahmed M, Bin Yousef H, Greer W, Faraz H, Al Sobhi S, Al Zahrani A, Raef H, Al Ghamdi A, Al Kadhi Y, Al Dayel F. Hurthle cell neoplasm of the thyroid gland. Anz Journal of Surgery. 2008; 78: 139-43. doi: 10.1111/j.1445-2197.2007.04389.x.

23. Barnabei A, Ferretti E, Baldelli R, Procaccini A, Spriano G, Appetecchia M. Hurthle cell tumours of the thyroid. Personal experience and review of the literature. Acta Otorhinolaryngologica Italica. 2009; 29: 305-11.

24. Singh B, Haigh PI, Kebebew E, Chabot JA, Saxe A. The treatment and prognosis of Hurthle cell follicular thyroid carcinoma compared with its non-Hurthle cell counterpart Discussion. Surgery. 2005; 138: 1157-8.

25. Montone KT, Baloch ZW, LiVolsi VA. The thyroid Hurthle (oncocytic) cell and its associated pathologic conditions A surgical pathology and cytopathology review. Archives of Pathology \& Laboratory Medicine. 2008; 132: 1241-50.

26. Foote RL, Brown PD, Garces YI, McIver B, Kasperbauer $\mathrm{JL}$. Is there a role for radiation therapy in the management of Hurthle cell carcinoma? International Journal of Radiation Oncology Biology Physics. 2003; 56: 1067-72. 